\title{
The Counseling Needs of Girls about to Get Married: A Qualitative Study of Taal of Association in Unayzah
}

\author{
Reem Ibrahim Alhussain ${ }^{1}$, Ahmad Bin Abdullah Al-Ajlan ${ }^{2}$ \\ ${ }^{1}$ PhD student, Faculty of Arabic Language and Social Studies, Department of Sociology and Social Work, Qassim University, \\ KSA. \\ ${ }^{2}$ Associate Professor, Head of Department of Sociology and Social Work, Qassim University, KSA.
}

\begin{abstract}
This study aimed at identifying the cognitive and skills needs of young women getting married by monitoring the reality in the rehabilitation program of young women getting married. This study adopted the qualitative approach, which focuses on studying the phenomena, the individuals, communities, and institutions in various fields and describing them to reach a deeper understanding. The study used two methods to collect data and information from the research sample. The Focus group tool, which was used with a purposive sample of (21) young women getting married and who attended the qualification program of young women getting married. The other tool was interviews with the trainers. The researcher had individual interviews with all the seven trainers. The results of this study revealed that the most important knowledge according to trainers is the psychological knowledge and the medical knowledge. The results showed also that the most important skills required in this program from the trainer's point of view were house management, grooming and personal care, and emotion control. The most important knowledge that has gained the favor of young women getting married in this program are psychological and medical knowledge. The most significant skills that young women getting married need are: the skill if dealing with the husband, the skill of emotion control, the skill of emotions management, the skill of planning, and the skill of problem solving. The study recommended using the rehabilitation programs with couples getting married and making such programs as a condition of the marriage contract. The study also recommended establishing a department in the Ministry of Labor and Social Development, which supervises the providers of pre-marriage counseling courses.
\end{abstract}

Keywords:

Pre-marriage counselling, women, rehabilitation programs, social skills, knowledge.

\section{Introduction}

Family is a very important component and has specific functions and tasks. Because of its vital role, a number of institutions have emerged in society that deal with family affairs. Among these institutions are the marriage and family care associations. One its goals is working towards spreading awareness and training those who are about to get married on the basics and requirements of the new married life. Taalouf Association in Al-Qassim Region is one of these associations, which was established to achieve a number of social and indicative goals. It seeks to provide social counseling services, as well as training those who are about to get married. The main motive behind the establishment of these associations is the increasing concern about the high rates of divorce, marital disputes and poor marital compatibility.

The social service became concerned with the family and the newly formed family, as it is one of the most important components that the social service workers deal with. The main purpose is helping new families to fulfill their role in society.
Marital rehabilitation should be provided through specialized institutions, such as institutions to facilitate marriage and family care. These institutions have experience and professional practice in dealing with those who are about to get married. Working in this sector requires an accurate and scientific identification of the guidance needs of those who want to get married. Determining the needs is a process characterized by flexibility, change and continuous change according to developments and new and urgent social transformations on the family structure and the marriage system.

\subsection{Problem Statement}

When a girl accepts marriage, she is establishing a new phase of her life, and this stage requires her to prepare for a set of tasks, responsibilities and roles that are different from her previous roles. Therefore, she needs to know the requirements of these new roles, especially after the increasing cases of disintegration in families, divorce, domestic violence and other family problems. These problems are because of the absence of 
family awareness and the correct understanding of marital life and its responsibilities; Moreover, marital rehabilitation is considered one of the components of increasing family awareness, which in turn leads to the continuation and success of marital and family life [1].

Each region of the Kingdom of Saudi Arabia has its cultural and social norms. It is not possible to generalize a rehabilitation program for girls entering marriage in a particular region without taking into account their social and cultural structure, as well as the knowledge and skill needs of girls entering marriage there. The priority knowledge or skill for this category of women in one region does not necessarily have the same priority and importance in another region. This is one of the shortcomings of the existing rehabilitation programs. Several important dimensions were not taken into consideration in the process of building rehabilitation programs. One of these dimensions is having the knowledge and skill needs of the category of women preparing for marriage.

Accordingly, this study aimed at highlighting this category of women to identify their indicative needs in the areas of knowledge and skills needed before marriage. Providing these women with knowledge and skills necessary to build a married life characterized by continuity and permanence and positive interaction are important requirements of this stage. Therefore, this study aims at identifying the most important cognitive and counseling needs for girls who are about to get married in Qassim region.

\subsection{Research Objectives}

This study seeks to achieve the following objectives:

1. Identifying the reality of the program of preparing women for marriage at Taalouf association from the viewpoint of the trainers.

2. Identifying the reality of the program of preparing women for marriage at Ta'alouf from the point of view of those who about to get married.

3. Identifying the most important counseling and knowledge needs for girls about to get married.

\subsection{Research Questions}

This study attempts to answer the following questions:

1. What is the reality of the rehabilitation program for women entering marriage at Taalouf from the trainers' point of view?

2. What is the reality of the rehabilitation program for women preparing for marriage at Taalouf from their point of view?

3. What are the most important skill needs for girls who are about to get married?

\subsection{Significance of the Study}

Identifying the counseling needs of those who about to get married in a scientific way will contribute to designing counseling programs that express a real need for the target group. In addition, this study highlights the scientific importance of what was recommended by some previous studies on the importance of determining counseling needs of women about to get married. The results of this study will contribute effectively to workers in marriage and family care associations in designing effective counseling programs to raise the abilities and skills of girls entering marriage.

\subsection{Limitations of the Study:}

Thematic limitations: This study addressed the counseling needs of girls who are about to be married and focused on the cognitive and skills dimensions.

Human Limitations: This study targeted girls who are about to be married, beneficiaries of the qualifying program for those who want to get married. The study also targeted the trainers who provide the rehabilitation program for those who want to get married at the Charitable Association for the Facilitation of Marriage and family care in the governorate of Unayzah (Taalof Association). Spatial limitations: This study was applied in the Charitable Association to Facilitate Marriage and Family Care in Unayzah Governorate (Taalof Association).

Time limits: The field application of the study was carried out in January and February 2017. 


\subsection{Definition of Operational Terms}

Needs: Linguistically, need is defined as what a person lacks and seeks. The counselling needs can be defined procedurally in this study as a set of social, psychological, legal, health, medical, social, psychological and life skills related to the formation of marital life and needed by girls who are about to get married.

Counseling before marriage: Counselling is an educational process that helps individuals to understand themselves, study personality, determine problems, develop potential, and solve problems in light of their knowledge, desire, education and training in order to achieve goals and reach a level of mental health [2].

Girls about to be married: In this study, girls about to be married are those girls who have entered in the marriage contract and attend the counseling program to qualify women who will enter marriage at the Association for the Facilitation of Marriage and Family Care in Unayzah Governorate.

\section{Literature Review}

\subsection{Marriage counseling}

Marriage Counseling is defined as the process of guidance, counseling, and treatment of problems related to young people's willingness to marry. The main purpose of counselling is encouraging marriage, removing its obstacles and strengthening the motivation for it. It also aims at solving problems and disputes that actually meet the spouses, and threaten their continuation as happy couples [3].

Marriage counseling aims to achieve the happiness of the small family and the larger community by teaching young people the basics of a happy married life, and working to bring together the most suitable spouses. This counselling also aims to be preventive, and help in solving and treating what may arise from marital problems or disturbances [2].
Each stage of growth includes financial, psychological and social needs and requirements that are imperative. These needs range from simple to complex needs. The individual, when satisfying the basic needs, searches for appropriate ways to satisfy other needs through relationships with others in the environment. If satisfaction is not achieved, this will lead to confusion and tension, which will be reflected not only on the individual but also on the society as a whole [4, 5].

The researcher believes that there are many counseling needs for those who want to get married, which varied in importance and priority according to the cultural and social environment, and the psychological characteristics of these girls. These needs revolve around providing those who are planning to get married with knowledge and skills that are appropriate for the new stage in their lives, and helping them achieve marital compatibility.

The study will focus on two types of counselling needs for girls entering marriage, namely, cognitive needs and skill needs, as any girl entering marriage needs to acquire marital life skills and knowledge about this life and its requirements.

\subsection{Previous Studies}

Reference [6] conducted a study on the effectiveness of training courses to qualify those who are about to get married in reducing marital disputes in the Saudi society. This study was applied in the city of Riyadh, and it used the correlational descriptive approach. The study sample consisted of 389 males and females about to get married who attended training courses at Abdulaziz bin Baz Foundation to rehabilitate those who are about to get married. The results of the study showed that the educational sessions reached the highest attendance rate, followed by psychological and then social courses. The results showed the sample's tendency to choose uncertainty, approval, and strong approval, and a marked departure from rejection and strong rejection.

Al-Shammari [7] conducted a study on determining the priorities of training programs for girls who are about to get married in the legal, 
social, psychological, health and economic fields. The study used the social survey through the intentional sampling method, which was applied to (52) girls who are about to get married in Ibn Baz charitable project. The results showed that the components and foundations of a happy married life according to what is mentioned in Islamic law, the skill of emotional communication, the skills of controlling emotions, the personal care of the wife, the skill of determining the financial priorities of the family.

Abu Al-Azm [8] conducted a study on the effectiveness of a professional intervention program in general practice in social service to develop awareness of family life for those who are about to marry. The study was applied in the examination office for those wishing to marry affiliated to the Family Planning Association in Benha City, Qalyubia Governorate. The sample consisted of 34 men who are about to get married. The study used the experimental approach. The results showed no statistically significant differences between pre-measurement and postmeasurement for the experimental group after applying the professional intervention program for social service within the general practice of developing awareness of those who are about to marry.

Reference [9] explored how culture and marital relationship programs improve communication between spouses. This study aimed also at identifying the fact that accepting the generalization about the effectiveness of marriage rehabilitation programs by reviewing the summary of the results of previous studies. This study used the evaluation approach. The sample consisted of 65 studies and reports to evaluate the effectiveness of marriage rehabilitation programs. The results of the review revealed that there is an effect of marriage rehabilitation programs on communication between spouses and the acquisition of positive behaviors that contribute to resolving marital disputes. This effect appears greatly in studies that follow the observation tool. The results indicated the importance of this tool and its effective role in showing the impact of marriage rehabilitation programs, and this shows the importance of employing the qualitative approach in this type of studies.
Several studies discussed the issue of marital counseling, especially after the spread of marital disputes, the high rates of divorce and family disintegration. These events prompted researchers to conduct studies related to marital counseling in an attempt to reach results that contribute to reducing marital problems, reducing divorce rates, achieving marital compatibility and success in marital relationship. Therefore, the researcher presented many different studies conducted in the Saudi, Arab, and foreign society, which are related to the subject of the study, and the researcher concluded from the previous presentation of the previous studies to several points. The majority of the previous studies were based on evaluating the effectiveness of pre-marital rehabilitation programs, most of which concluded the need to work on developing these programs in line with the needs of those entering marriage and the requirements of social change. Some studies dealt with the awareness level of the requirements of married life, and the results showed a decrease in awareness of those entering marriage of the requirements of married life. The majority of the previous studies were based on the descriptive approach, both analytical and correlational, and used the questionnaire tool to collect data.

The researcher used the results of previous studies and the proposed recommendations in drafting the title of the study, as most of the previous studies recommended the necessity of conducting many studies dealing with pre-marital counseling, and identifying the needs of those who are about to get married. In addition, the researcher used these studies in formulating the research problem and building the theoretical and methodological framework.

\section{Research Methodology}

This section provides information on the methodology of the present study, which includes population and sample, research instrument, and validity and reliability of the instrument.

\subsection{Population and Sample}

The population of the study consisted of girls who are about to get married, who are enrolled in the pre-marital rehabilitation program at the 
Charitable Association to Facilitate Marriage and Family Care in Unayzah Governorate (Ta'alof Association). The population also included the trainers who trained women who are about to get married in the same association.

The researcher used the method of comprehensive inclusion of all members of the study population from the trainers, and the girls who are about to get married who attended the rehabilitation program for the women to marry in Ta'alof Association. This method is consistent with the study population and serves the research objectives, as the comprehensive inclusion method is characterized by obtaining all data and information about the study problem.

\subsection{Research Instruments}

The study relied on two instruments in collecting data and basic information from the research population.

\subsubsection{Focus Groups}

In this method, the interview and dialogue take place with a small group of participants together in a known location. The researcher plays the role of facilitator intrinsically, and her job is to lead discussions and ensure everyone has an opportunity to respond. Focus groups allow for a more in-depth study. This is because when they hear other people speaking, it often elicits answers, or ideas that they had not thought of before [10].

The researcher implemented a guide for the focus group, and presented it to a number of judges. It was modified in accordance with the objectives of the study, which included the primary data of the study sample. The data collected included age, educational level, arrangement between family members, the marital status of the parents, the educational level of the mother, the educational level of the father, the age of the spouse, his educational level, the relationship of kinship with him, the duration of the engagement, attending counseling courses on marriage, the motivation to attend a qualification course for marriage, reviewing married life books, and viewing programs on married life.

\subsubsection{Interviews}

Interviews used in this study included questions that are not precisely defined, nor is the response to these questions determined in advance. Rather, they give the researcher great flexibility to delve into obtaining the information that serve the research objectives [11].

The researcher used this tool with the trainers who provide the rehabilitation program for girls who are about to get married at the Charitable Association for Family Care (Taalouf). This tool is appropriate to achieve the goals of the study.

The researcher designed the interviews guide for trainers and presented it to a group of judges to verify the validity of the tool. The guide included the primary data (academic qualification, years of experience, the role of the trainer, the problems received from the newlyweds).

\subsubsection{Validity of the instruments}

The researcher conducted a content validity on both instruments. The researcher presented the two study tools to (9) of experienced and specialized judges from university professors, who are related to the subject of the study. The purpose was to know the extent of the validity of the two study instruments in measuring what they set to measure. The researcher used the judges' observations and directions to produce the instruments in their final form.

\subsection{Data Collection}

The study relied in collecting data on the on two instruments. The first was focus group with those who want to get married. The second was interviews with the trainers. The researcher conducted interviews and discussions in Taalouf association in Unayzah Governorate, due to the availability of the study sample, and the difficulty of meeting with them elsewhere. The sequence of some questions was changed and others were added according to the course of the interview. These interviews were recorded in special records to be reviewed and transcribed.

The duration of the discussions in the focus groups lasted from 90 to 100 minutes for each group, where the number of participants in the focus groups was 21 participants. They were 
divided into 4 groups, each group contained 5 participants except for the fourth group that contained 6 participants. The duration of individual interviews with trainers lasted from 30 to 60 minutes for each trainer. Their number was seven trainers and one interview was conducted with each trainer daily.

\section{Findings and Discussion}

This section provides the findings obtained from the present study. These findings are presented based on the research questions that guide the present research.
Results of the first question

"What is the reality of the rehabilitation program for women entering marriage at Taalouf from the trainers' point of view?"

This question aims to identify the reality of the program for the rehabilitation of women entering marriage from the viewpoint of the trainers in the program. To answer this question, the researcher conducted individual interviews with the trainers. The results of these interviews were analyzed through organizing, classifying, and coding the data by displaying them in frequency and percentage calculation. The following tables illustrate these results.

Table 1. The reality of the program of rehabilitating women entering marriage from the viewpoint of the trainers

\begin{tabular}{|c|c|c|c|}
\hline The reality of the program & Phrases & No. & percentage \\
\hline \multirow{2}{*}{$\begin{array}{l}\text { Did the rehabilitation program for } \\
\text { girls entering marriage address all } \\
\text { their counseling needs from your } \\
\text { point of view? }\end{array}$} & Yes & - & 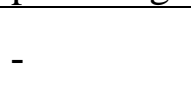 \\
\hline & No & 7 & $\% 100$ \\
\hline \multirow{8}{*}{$\begin{array}{l}\text { From your point of view, what are } \\
\text { the most important problems that } \\
\text { can be solved by the pre-marriage } \\
\text { program? }\end{array}$} & Marital Infidelity & 3 & $\% 42.85$ \\
\hline & Emotional drought & 1 & $\% 14.28$ \\
\hline & Financial problems & 1 & $\% 14.28$ \\
\hline & Lack of dialogue between spouses & 3 & $\% 42.85$ \\
\hline & Problems with the husband's family & 2 & $\% 28.57$ \\
\hline & $\begin{array}{l}\text { Problems of the wedding night and } \\
\text { intimacy }\end{array}$ & 2 & $\% 28.57$ \\
\hline & $\begin{array}{l}\text { Medical problems related to } \\
\text { contraception }\end{array}$ & 2 & $\% 28.57$ \\
\hline & $\begin{array}{l}\text { Failure to bear responsibility by the } \\
\text { husband }\end{array}$ & 1 & $\% 14.28$ \\
\hline \multirow{7}{*}{$\begin{array}{l}\text { What are the causes of these } \\
\text { problems? }\end{array}$} & The weakness of religious faith & 2 & $\% 28.57$ \\
\hline & bad company & 1 & $\% 14.28$ \\
\hline & $\begin{array}{l}\text { Lack of awareness of managing } \\
\text { financial matters }\end{array}$ & 1 & $\% 14.28$ \\
\hline & $\begin{array}{l}\text { Openness and easy access to the } \\
\text { outside world }\end{array}$ & 4 & $\% 57.14$ \\
\hline & $\begin{array}{l}\text { Ignorance of spouses of the basics } \\
\text { of married life }\end{array}$ & 3 & $\% 42.85$ \\
\hline & $\begin{array}{l}\text { Ignorance of the rights and duties of } \\
\text { both spouses }\end{array}$ & 3 & $\% 42.85$ \\
\hline & $\begin{array}{l}\text { Lack of marital life skills, such as } \\
\text { dealing with flexibility, having } \\
\text { methods of dealing with marital }\end{array}$ & 3 & $\% 42.85$ \\
\hline
\end{tabular}


problems, preventing them, and managing the family budget.

Failure to understand the nature and needs of the man

Husband's consumption
masturbation before marriage of 1 \% 14.28

Distortion of the image of marriage

by the media

Foundations of married life and its stages

Table (1) shows the reality of the programs for rehabilitating women entering marriage from the trainers" point of view regarding the approach of the program for qualifying girls about to get married to all their counseling needs. These programs can solve different problems and reduce the reasons that lead to them. Four trainers emphasized the importance of the good advertisement for the training session, and the creation of advanced methods in line with the development and technical progress to attract the largest category of those who want to get married.

Four of the trainers emphasized the importance of experiences in raising community awareness of the vital role of rehabilitation programs for women entering marriage. In addition, they mentioned the need for experiences during the launch of the advertisement for the program.

While a group of trainers believed that the program should be held in places where girls gather, such as schools and universities. Many women want to get married and want to attend the program, but they have obstacles that prevent them from doing so, such as means of transportation or the family's lack of awareness of the importance of the program. Therefore, facilitating the programs in their locations help them in achieving benefits from the programs. One of the trainers suggested providing transportation for those who wish to attend the program.

Two other trainers believed that adding financial incentives to those who attend the program will contribute to increasing the demand for the program. One trainer mentioned, "even if the girl attended because of the incentives, she must receive a benefit from the program."

While one of the trainers suggested the need to choose the appropriate timing for the program. She said "that the girl entering marriage is busy providing the requirements for marriage, and the appropriate time must be chosen for her, because she is trying to make herself available so that she can benefit from the program).

Results of the second question

"What is the reality of the rehabilitation program for women preparing for marriage at Taalouf from their point of view?"

The researcher analyzed the contents of the training package for the rehabilitation program for girls intending to get married with the aim of being acquainted with the reality of the Rehabilitation Program. Therefore, the analysis tables included all knowledge, skills, methods, and training methods for the program.

In order to answer this question, the researcher covered several aspects to learn about the reality of the program of rehabilitating women intending to marry from their own point of view. The researcher then discussed these aspects with the focus groups and drew conclusions and results as shown in Table 2.

Table 2. The reality of the program for the rehabilitation of women entering marriage from their own point of view 
marital life in the rehabilitation program for girls entering marriage

\section{Marriage goals}

The Marriage Contract

(its concept, elements, 1 and conditions)

Knowledge related to the Sharia and economic aspects of marital life

Rights and duties

between spouses

Provisions and violations

of the wedding night

group

group

group

group

The foundations and

stages of a successful 3

21

3

$\% 14.2$

marriage

Family budget (concept and benefits)

Psychological

characteristics of men 5

$5 \quad 3$

5

18

$\% 85.7$

Knowledge related to the psychological aspect of marital life and women

Emotional satisfaction between spouses

3

5

2

3

13

$\% 61.9$

Factors that help create

the passion of love 5

between spouses

The intimate relationship

between spouses

4

The stages of the

intimate relationship 4

5

3

3

16

$\% 76.1$

Knowledge related to between spouses

the health aspect of The differences between

married life

men and women in the

practice of intimacy

Misconceptions about

intimacy for men and 2

3

2

6

$15 \quad \% 71.4$

women

The anatomical

differences of the

Knowledge related to genitals of men and

6

16

$\% 76.1$

the medical aspect of married life

women

vulvovaginitis and ways

to prevent it

3

Ovulation

and 3

$6 \quad \% 28.5$


fertilization

Birth control
$\begin{aligned} & \text { Smoking and its impact } \\ & \text { on the marital }\end{aligned}$

Table (2) illustrates the knowledge that was addressed in the program of rehabilitating women who want to marry from their own point of view. These results are consistent with the results of individual interviews on organizational aspects, which indicates that these proposals will contribute to increasing the effectiveness of the program. The repetition of these proposals by the two study samples confirms their importance. For training methods, the participants emphasized the need to diversify them. Diversification, from their point of view, contributes to better information delivery and confirmation to all beneficiaries of the program. In addition, making the program lively and interesting contributes to increasing the demand for it by those who want to get married.

The participants also expressed the need for the training package to be brief. This is because the approved package contains a huge number of knowledge that women about to get married do not need, and do not meet their cognitive and skill needs. Such category of women needs a brief training package that contains clear and smooth practical applications for all beneficiaries of the program regardless of their different mental abilities, and their level of awareness of married life.

A group of participants proposed to add a program as an annex to the current program for the rehabilitation of mothers of girls about to be married. The purpose is to reduce the conflict for those who are preparing to marry between what they learn in the program and what they receive from the parents in terms of knowledge and skills.

Some participants also suggested that there should be a special program for married women, independent of the program for those who want to get married. The participants suggested that the trainer should be a specialist in the topic she provides. On the social side, for example, it is presented by specialists in sociology and social work. In the psychological side, the trainer should be presented by specialists in psychology and so on to cover the needs of every category.

With regard to the trainers' commitment to their areas, the participants emphasized the great importance of this suggestion for its positive impact on the target group of women who want to get married. The commitment of each trainer to her own area helps to eliminate the interference, confusion and conflict in the knowledge that is presented, and thus contributes to the clarity of knowledge and skills and increases their credibility.

A group of participants suggested that presenting topics about men to be provided by a male trainer. They believe that men know the way other men think and are aware of the characteristics of men more than women are. Moreover, a group of participants suggested that the trainer should take into account social change in the knowledge and skills that she provides. It is not possible to provide knowledge or mention outdated examples that do not correspond to the current generation of men. One participant stated "what is presented in the session does not fit with men at the present time."

\section{Results of the third question}

"What are the most important skill needs for girls who are about to get married?"

To answer this question, the researcher presented this question to each group and gave them an 
opportunity to discuss and draw conclusions. The responses were analyzed, classified, and coded by presenting frequencies and percentages as shown in the following table.

Table 3. The skill needs of girls about to be married

\begin{tabular}{|c|c|c|c|c|c|c|c|}
\hline $\begin{array}{l}\text { The skill } \\
\text { needs of girls } \\
\text { about to be } \\
\text { married }\end{array}$ & Sub-skills & $\begin{array}{l}\text { first } \\
\text { group }\end{array}$ & $\begin{array}{l}\text { second } \\
\text { group }\end{array}$ & $\begin{array}{l}\text { third } \\
\text { group }\end{array}$ & $\begin{array}{l}\text { Fourth } \\
\text { group }\end{array}$ & Total & $\begin{array}{l}\text { percent } \\
\text { age }\end{array}$ \\
\hline \multirow{8}{*}{$\begin{array}{l}\text { Skills related } \\
\text { to the social } \\
\text { aspects of } \\
\text { marital life }\end{array}$} & $\begin{array}{l}\text { The skill of } \\
\text { dealing with the } \\
\text { husband }\end{array}$ & 5 & 5 & 4 & 6 & 20 & $\% 95.2$ \\
\hline & $\begin{array}{l}\text { The skill of } \\
\text { dealing with the } \\
\text { husband's family }\end{array}$ & 5 & 4 & 4 & 4 & 17 & $\% 80.9$ \\
\hline & $\begin{array}{l}\text { The skill of } \\
\text { dialogue }\end{array}$ & 3 & 2 & 3 & 4 & 12 & $\% 57.1$ \\
\hline & $\begin{array}{l}\text { The skill of } \\
\text { request }\end{array}$ & 2 & 1 & 1 & 3 & 7 & $\% 33.3$ \\
\hline & $\begin{array}{l}\text { The skill of social } \\
\text { intelligence }\end{array}$ & 3 & 5 & 3 & 2 & 13 & $\% 61.9$ \\
\hline & $\begin{array}{l}\text { The skill of social } \\
\text { support }\end{array}$ & 3 & 5 & 2 & 2 & 12 & $\% 57.1$ \\
\hline & $\begin{array}{l}\text { The skill of } \\
\text { cooperation and } \\
\text { participation }\end{array}$ & 1 & - & 1 & - & 2 & $\% 9.5$ \\
\hline & $\begin{array}{l}\text { The skill of } \\
\text { respect } \\
\text { appreciation }\end{array}$ & 2 & - & 2 & 2 & 6 & $\% 28.5$ \\
\hline \multirow{5}{*}{$\begin{array}{l}\text { Skills related } \\
\text { to the } \\
\text { psychological } \\
\text { aspects of } \\
\text { married life }\end{array}$} & $\begin{array}{l}\text { The skill of } \\
\text { managing feelings }\end{array}$ & 4 & 5 & 3 & 6 & 18 & $\% 85.7$ \\
\hline & $\begin{array}{l}\text { The skill of } \\
\text { controlling } \\
\text { emotions }\end{array}$ & 4 & 5 & 5 & 5 & 19 & $\% 90.4$ \\
\hline & Adaptation skills & 3 & 3 & - & - & 6 & $\% 28.5$ \\
\hline & Skills of apology & 3 & 5 & 3 & 3 & 14 & $\% 66.6$ \\
\hline & $\begin{array}{l}\text { Body language } \\
\text { skill }\end{array}$ & 3 & 3 & 3 & 3 & 12 & $\% 57.1$ \\
\hline \multirow{5}{*}{$\begin{array}{l}\text { Skills related } \\
\text { to the life } \\
\text { aspects of } \\
\text { married life }\end{array}$} & Planning skill & 5 & 5 & 5 & 4 & 19 & $\% 90.4$ \\
\hline & $\begin{array}{l}\text { Skill of crisis } \\
\text { management and } \\
\text { problem solving }\end{array}$ & 4 & 4 & 4 & 6 & 18 & $\% 85.7$ \\
\hline & $\begin{array}{l}\text { Home } \\
\text { management skill }\end{array}$ & 5 & 2 & 5 & 5 & 17 & $\% 80.9$ \\
\hline & $\begin{array}{l}\text { The skill of taking } \\
\text { responsibility }\end{array}$ & - & 2 & 1 & - & 3 & $\% 14.2$ \\
\hline & $\begin{array}{l}\text { The skill of } \\
\text { personal care }\end{array}$ & 4 & 5 & 4 & 6 & 19 & $\% 90.4$ \\
\hline
\end{tabular}


Participants expressed the importance of these skills because they help in interaction and communication well with the other spouse and reflect positively on married life. Discussions in focus groups have concluded the need for many social skills necessary for the stability of married life.

These results are consistent with other studies [7], which reached a set of priorities for training programs for girls who are about to get married, such as the skill of dealing with the husband and his family.

The results of the discussions concluded that the participants have an urgent need for many life skills. The current circumstances necessitated the availability of a house cleaner in every home, which, from their viewpoint, contributed to their lack of life skills that would help them manage their new life well. This result is consistent with the results of individual interviews of trainers, who believe that the most important skills that must be acquired for those who want to get married are life skills.

\section{Recommendations}

In light of the findings of the study, the study presents a number of recommendations that may contribute to satisfying the counseling needs of those who are planning to get married, and thus achieving social and marital harmony for them. The Ministry of Labor and Social Development could follow up on premarital counseling programs and conduct studies and research on them to ensure their effectiveness. The Ministry of Labor and Social Development could also appoint social workers and social researchers to conduct periodic research on the indicative needs of women intending to get married in all regions of the Kingdom, and to design counseling programs in light of the results of field studies and research. It is recommended to improve and develop programs for the rehabilitation of those who want to marry according to the social changes and the consequent change in the knowledge and skill needs of the target group of the program.

\section{References}

[1] Al-Ghamdi, M. S. "Marriage rehabilitation programs and their impact on marital life: a field study on a sample of married Saudi youth in Jeddah". Journal of the Faculty of Arts: Zagazig University - Faculty of Arts, 54 (2010): 277-321. Retrieved from http://search.mandumah.com/Record/36343 $\underline{4}$

[2] Zahran, H. A. "Psychological Guidance and counseling". Cairo: Alam Al-kutub. 2005.

[3] Saud, N. S. and Al-Halabi, H. K. "Family and marital counseling". Riyadh: Dar Al Zahraa. 2013.

[4] Al-Nahi, E. M., Al-Kawaz, U. G. \& AlZubaidi, M. K. "Comparative study of the counseling needs between students in first grade and the fourth grade in the College of Sport Education in University of Mosul". Al-Rafidain for Sports Sciences, 19 (63), 2013. p. $1-15$. https://search.emarefa.net/detail/BIM$\underline{333391}$

Bin Askar, M. A. \& Al-Sibilah, M. A "Surveying the opinions of Saudi youth about the counseling program before marriage". $\quad$ Dafater. 2018. http://revues.univbiskra.dz/index.php/dftr/article/view/2565.

[6] Al-Shammari, H. H. "The effectiveness of training courses to prepare those who are about to get married in reducing marital disputes" (Unpublished Master Thesis). Naif Arab University for Security Sciences, Riyadh, College of Graduate Studies, Department of Social and Psychological Sciences. 2013.

[7] Al-Shammari, B. M. "Determining priorities for training programs for girls intending to get married". (Unpublished Master Thesis). Imam Muhammad bin Saud University, Riyadh, College of Social Sciences, Department of Sociology and Social Work. 2016.

[8] Abu Al-Azm, J. M. "The effectiveness of a professional intervention program in general practice in social work to develop awareness of those who are about to marry 
Review Article

about family life". (Unpublished $\mathrm{PhD}$ thesis). Helwan University, College of Social Work, Department of Social Work fields. 2010.

[9] Hawkins, A. J., Stanley, S. M., Blanchard, V. L., \& Albright, M. "Exploring programmatic moderators of the effectiveness of marriage and relationship education programs: A meta-analytic study". Behavior therapy, 43(1). 2012. Pp 77-87.

https://doi.org/10.1016/j.beth.2010.12.006.

[10] Bacherji, A. "Social Science Research". (Translated by Hayyan and Khaled Nasser), Amman, Dar Al-Yazuri. 2015.

[11] Rajab, I. A. "Research methods in the social sciences". Riyadh: Dar alam alKutub. 2003. 